\title{
Achieving Sustainable Organisational Performance through Employee Job Satisfaction and Organizational Culture
}

\author{
Muhammad Imran ${ }^{1}$, fadillah Binti Ismail ${ }^{1}$, Khawar Hussain ${ }^{1}$ and Pratik Kumar Singh ${ }^{1}$, Abdul Aziz Ansari $^{2}$ \\ ${ }^{1}$ Faculty of Technology Management And Business, Universiti Tun Hussein Onn Malaysia, 86400 Parit Raja, Johor, Malaysia. \\ ${ }^{2}$ Department of Civil Engineering,Faculty of Engineering, Science, Technology and Management. (ZUFESTM), \\ Karachi,Pakistan.
}

\begin{abstract}
The reason for this examination is to inspect the intervening function of occupation fulfillment on the connection between the components of authoritative culture, association culture, consistency culture, flexibility culture and mission culture with hierarchical execution on the financial segment of Pakistan. This investigation was directed to advance the idea of hierarchical culture out in the open banks with the goal that it very well may be reflected in the exhibition of the bank. The example of this investigation comprises of 320 including branch chief (BM), provincial supervisor (RM), operational director (OM), and colleague branch administrator (ABM) workingin eight public banks inside the region of Punjab and Sindh,Pakistan.Dimensions of hierarchical culture weremeasured by a prior approved 12 item instrument, work fulfillment 16 things and authoritative execution were estimated by 7 things. Factor examination was utilized to develop four elements of hierarchical culture (i.e., contribution culture, consistency culture, versatility culture and mission culture). The connection between hierarchical culture measurements, work fulfillment, and authoritative execution was tried by SmartPLS 3.2.9.Among the variousdimensions of authoritative culture, inclusion culture, versatility culture and mission culture had a critical, positive relationship with work satisfactionalso as hierarchical execution. Moreover, consistency culture displayed the most grounded, negative relationship however huge impact on work fulfillment, while consistency culture indicated aninsignificant impact, negative relationship with hierarchical performance.Bank administrators and policymakers ought to be cognizant that circumspect the authoritative culture can assist them with figuring out where to endeavor to help increment their worker work fulfillment and bank execution. The aftereffects of this investigation could likewise be helpful to bank leaders who wish to broaden authoritative execution. Improving worker work fulfillment inside the work environment may expand productivity and help guarantee steady and effective representatives.
\end{abstract}

\section{Introduction}

A few nations, including Pakistan, have built up the possibility of sociologies because of expanding advancements, which adds to the difficulties of the superfluous circumstance. Hierarchical execution has become a significant part of accomplishing a maintainable upper hand (Akram, Goraya, Malik, and Aljarallah, 2018). Hierarchical execution is the limit with regards to an association to fulfill its primary objective through sound administration, solid organization and a decided pledge to accomplishing specific goals over a given time span (Awuor, 2015). Execution is similarly described as the accomplishment of monetary and non-budgetary related goals that engages an association to remain sensible and handy both incidentally and in the long run(Saira Yousaf, Madiha Latif, 2012)Organizational execution might be an outcome of the adequacy of the exercises that a partnership undertakes(Chienwattanasook and Jermsittiparsert, 2019). Execution isn't intended for the point of what associations animate an establishment; really, it's concerning the conduct of the laborers inside the association. The view of hierarchical execution is said to endurance additionally due to the accomplishment of an enterprise (Ahmed and
Shafiq, 2014). Hierarchical execution incorporates the viability and productivity of organizations(Arifeen et al., 2014).However, authoritative culture has been a region of consideration for quite a long while and culture demonstrates a major consider hierarchical performance(Yesil and Kaya, 2013) to discover how authoritative representatives' methodology and practices work execution and hierarchical execution influenced. Various definitions are proposed for authoritative culture and a large portion of them have concurred that it's a people-focused conduct that blends interior and outer viewpoints and might be given to an alternate group(Shahbaz, Soomro, Soomro, Sohu, and Ahmed, 2020). In view of Denison and Mishra (1995), authoritative culture comprises of 4 highlights that assist associations with expanding their exhibition. These are inclusion culture, consistency culture, versatility culture and mission culture (Denison and Mishra, 1995). they tend to be sure about their main goal, where is that the association working, is there a concise period or while and why they are doing exist. The association slopes to have some consistency inside the association with the goal that they can get things done during a contending approach. Inclusion is a 
critical measurement in high-performing associations by including representatives at deal with a day today. They're additionally incredibly versatile associations by observing what's going on inside the market and reacting to those changes. These associations could answer to varieties inside the business setting, giving representatives a straightforward vision and course for the more term(Fey and Denison, 2003).It is noticed that activity fulfillment might be an intervening impact on the association among authoritative culture and hierarchical execution which makes a connection among association and workers to comprehend authoritative goals and to lessen workers' instability, which keeps the specialist from leaving his/her job.Besides, work fulfillment is experiencing numerous interior and outer components, such as working conditions, pay, advancement and oversight (Belias, Koustelios, Vairaktarakis, and Sdrolias, 2015). Occupation fulfillment underpins in generatingcompetent and inspired staff and causes association representatives to ask information, aptitudes, and experience to shape work position (Al-Abdullat and Dababneh, 2018).

\section{Literature review}

\subsection{Organizational culture}

Hierarchical culture is that the most by and large perceived issue, notwithstanding, a urgent human asset device that has gotten the attention of numerous analysts (Genc, 2017). In any case, it's been broadly utilized with clashing methods(Zahari and Shurbagi, 2012).An authoritative culture is a critical device that has been executed during a few segments to watch work fulfillment during such an association, including the financial division. Hierarchical culture has been utilized reliably which brings about segregation, bias, disappointment, and hence there's a magnificent logical inconsistency inside the utilization of this strategy (Chatman and O'Reilly, 2016). The power of authoritative societies is affected by numerous components, similar to such an association, the structure, and along these lines the way to deal with unrivaled administration (Al-Abdullat and Dababneh, 2018). Thus, the elements of authoritative culture existing in an association are extremely significant, on the grounds that it's a solid impact on progress prerequisites, including quality, viability, and proficiency. Along these lines, it's imperative to know how the components of authoritative culture encourage the hierarchical cycle since it is that the establishment of the achievement of anorganization (Abubakre, Coombs, and Ravishankar, 2014). Associations that are genuine about execution advance a climate and a culture that upholds maintainable exhibition. Making a worker inviting society is that the essential structure of any association, and will be viewed as while presenting authoritative procedures.

\subsubsection{Involvement culture}

As indicated by Denison and Mishra, (1995), inclusion culture is worried about the responsibility of the worker and the amount they cooperate to complete authoritative targets (Shahbaz, Othman, Salman, Memon, and Rasi, 2020).The association with outrageous level for a contribution culture by and large urges representatives to be more associated with their working environment and with other hierarchical workers in the work zone. Representatives in these associations demonstration effectively and accomplish additional work intentionally. Worker contribution to the association is high, originating from a hearty view of possession. Associations with an inclusion culture accept that dynamic might be an aggregate system and will be controlled in commitment with workers, to broaden the comprehension and effectiveness of choices and simplicity implementation(Denison, Nieminen, and Kotrba, 2014).

\subsubsection{Consistency culture}

The way of life of consistency is generally found in an association with a strong culture.These associations show steadiness, in that representatives normally acknowledge as obvious with one another. The consistency culture incorporates coordination, reconciliation, qualities, and arrangement, and representatives who work inside a consistency culture are by and large have clear bearings while in transit to work, with direction and straightforward code of conduct. At the point when associations outline a consistency culture they tend to have elevated levels of inward promotions(Denison et al., 2014).

\subsubsection{Adaptability culture}

A versatility culture requires making change, that has some expertise in shoppers and hierarchical learning. Associations scoring high for versatility will be prepared to watch and react to things and their clients, and redesign their practices and methods to allow variation (Fey and Denison, 2003). The association will be prepared to acknowledge and utilize signs from the unessential climate, fundamentally from clients and contenders, to switch interior practices and assent greater improvement. The association likewise will react to the needs of its workers, since they're dealt 
with interior clients over all levels, jobs and duties(Denison et al., 2014).

\subsubsection{Mission culture}

An association with a mission culture includes a solid feeling of hierarchical direction and sets a straightforward vision. A mission culture covers arranging vital course and aim and setting long haul hierarchical targets, objectives, and vision for the association. An enterprise that scores significantly for a mission culture will be prepared to grasp their external climate by achieving stability(Denison et al., 2014). The social association of the association and its outside consideration are plainly expressed, and execution is chosen by the ability to fortify representatives and associations to spend significant time in goals(Denison et al., 2014).

\subsection{Job satisfaction}

As per (Spector, 1997), work fulfillment might be an exploration theme related with hierarchical conduct, authoritative brain science, and add to the monetary part. Employment fulfillment, a thought that is habitually concentrated in hierarchical conduct research, is typically thought of as a positive variable that outcomes from inspecting an individual's work insight (Yuen, Loh, Zhou, and Wong, 2018). Worker work fulfillment is considered a test freely segment organizations(Top, Akdere, and Tarcan, 2015). it's intense for laborers inside the financial division to know the personality of worker work fulfillment and its impact on the overall presentation of the organization(Zeffane and Bani Melhem, 2017). Authoritative researchers are fortifying the connection between work fulfillment and hierarchical execution. Analysts have found some kind of harmony between work fulfillment and hierarchical execution during a positive way that a fulfilled representative influences the overall presentation of banks (Al-dalahmeh et al., 2018). The observational writing recommends that worker jobsatisfaction is that the way to hierarchical execution (Rahman, 2014; Kanyurhi and Bugandwa Mungu Akonkwa, 2016; Partono Prasetio et al., 2017; (Pang and $\mathrm{Lu}$, 2018). Past investigations have indicated less examination on work fulfillment openly part associations as far as authoritative culture (Belias et al., 2015; Hassan and Jagirani, 2019). Researchers concur that if the bank's workers are regularly made more fulfilled, their presentation is frequently improved, which progressively builds the association's performance(Nath Gangai and Agrawal, 2015). Representatives who are happy with the work with an authoritative culture demonstrate the degree to which workers have gone to improve hierarchical
performance(Osabiya, 2015). A few scientists likewise examined the association between work fulfillment with various factors (Fu and Deshpande, 2014; Crispen Chipunza, 2017; Gul et al., 2018). Davoodalmousavi, (2013) considered the relationship of contribution culture, consistency culture, versatility culture, and mission culture with work fulfillment. Jamshed and Siddiqui, (2020) have likewise directed an investigation on the association of hierarchical culture, work fulfillment, and performance. The scientist's fantastic information on the size of authoritative societies (i.e., inclusion, consistency, flexibility, and mission) and subsequently the part of employment fulfillment middle people about hierarchical execution is thought little of. The specialist is of the view that when the way of life of the associations (public banks) include their workers inside the dynamic cycle and representatives feel mental proprietorship, where chiefs and workers share a standard attitude and agreement, where the ability to shape inner changes in light of outside conditions is customary, and where there's a drawn out vision that has segments like key course and expectations, objectives and goals and vision then workers of public area banks will be fulfilled from their activity and it'll increment authoritative execution.

\subsection{Organizational Performance}

Authoritative execution might be a result of the adequacy of the exercises that a company embraces (Mohammed and Hammad, 2018). Execution isn't intended for the point of what associations cause in the establishment; really, it's concerning the conduct of the laborers of the association. Bhat and Beri, (2016) believed that presentation should gauge both the center exercises, task execution and logical execution. The assignment execution contains procedural information, specialized undertakings experience, with respect to the work. On the contrary hand, relevant execution isn't connected with specialized exercises yet help the hierarchical and social climate (Bhat and Beri, 2016). Authoritative execution may be associated with commercial center bearing, association learning, human resource productivity, quality improvement, or another factor (Ahmad, 2014). Hierarchical execution has been the key subject for associations be it benefit or non-benefit association. predictable with Sohail et al., (2017), authoritative execution is a pivotal variable in the board research and potentially the first significant marker of hierarchical execution. it's basic for chiefs to comprehend which highlights control an association's presentation in regard for them to require precise strides to start them. Nonetheless, it's not been anything but difficult to characterize, and estimating performance.According to Sanda and Kuada, (2016)banks' hierarchical exhibition is legitimately 
impacted by the association between authoritative culture and occupation fulfillment. The way of life of an enterprise includes an enduring effect on the presentation and it's a key consider deciding the association's success(Shahbaz, Mubarik, Mubarak, and Irshad, 2019). Solid societies improve authoritative execution since they make a significant level of inspiration for laborers. Measurements of Organizational culture (inclusion, consistency, versatility, and mission) won't just impact the more drawn out term execution of the banks where applicable, however it'll additionally diminish the damaging results of bank relations with their partners because of the emergency (Leskaj, Lipi, and Ramaj, 2013). By setting up systems and structures through the authoritative culture that cultivate new ideas and perspectives and working, this is frequently liable to direct to improved execution (Uzkurt, Kumar, Kimzan, and Eminoğlu, 2013). Nikpour, (2017)stated that every one element of hierarchical culture association, consistency, versatility and mission influence various parts of authoritative execution.

\section{Development of study model and hypothesis}

The essential reason of this examination is that an association with a culture of four social measurements that advance worker work fulfillment in the financial division, accordingly, can possibly accomplish high authoritative execution. The model is introduced in Figure 1.

Measurements of hierarchical culture and authoritative execution

Various explores (Prajogo and McDermott, 2011); (Uzkurt et al., 2013;Mousavi et al., 2015; Valmohammadi and Roshanzamir, 2015; Sadighi, 2017; Cheema and Abbas, 2017) have set up that the hierarchical culture includes a positive relationship with authoritative execution. At the point when the hierarchical workers are included inside the choosing of the association, there'll be a positive relationship with authoritative execution. As indicated by (Kotrba et al., 2012)consistency has huge beneficial outcomes on hierarchical execution. Association and consistency have a positive relationship with execution (Bandara, 2015). While different analysts (Mousavi et al., 2015) uncovered that inclusion and flexibility influence the exhibition of banks. Despite the fact that Yilmaz and Ergun, (2008), results showed that the mission culture is that the most unmistakable of the four dimensionsof authoritative culture, association culture, consistency culture, and versatility culture regarding expanded in general firm execution. A few researchers like (Nikpour, 2017; Gyebi, 2016; Cheema and Abbas, 2017; Zakari et al., 2013)also showed that there's a positive and critical connection between generally authoritative culture, contribution culture, consistency culture, versatility, culture, and mission culture with hierarchical performance. The results have upheld the thinking that when the authoritative culture of the association specific banks is reliable, a straightforward mission, worker inclusion inside the choosing, and representative ready to adjust development eventually hierarchical execution will be expanded in explicit bank execution. the resulting speculations are outlined by the past researcher established on the previously mentioned writing.

H1: Involvement culture is positively and significantly related to organizational performance.

$\mathrm{H} 2$ : Consistency culture is positively and significantly related to organizational performance.

H3: Adaptability culture is positively and significantly related to organizational performance.

$\mathrm{H} 4$ : Mission culture is positively and significantly related to organizational performance.

Dimensions of organizational culture and job satisfaction

Lund, (2003) uncovered that hierarchical culture connects with work fulfillment. Likewise,San Park and Hyun Kim, (2009) have additionally been discovered that there's a positive connection between hierarchical culture and employment fulfillment. also, Bellou, (2010)discussed that a vigorous connection between authoritative culture and worker work fulfillment. the measure of past explores of different specialists (Muhammad Arifin, 2015; Yildirim et al., 2017;Crispen Chipunza, 2017)has found that authoritative culture influences work fulfillment decidedly and fundamentally. In the event that authoritative culture is objective arranged and worker inclusion in hierarchical choosing for estimating hierarchical execution progressively they will be happy with there association and more exertion to fortify their efficiency and institutional execution will be additionally expanded. Besides, some imperative contention get from Qazi et al., (2017)that authoritative culture and employment fulfillment depends. Kotrba et al., (2012)research outcomes show that consistency exhibited a positive and huge connection between fulfillment. Furthermore, another exploration has been led between authoritative culture and understudy fulfillment 
Raju Uprety, (2014)revealed that contribution, flexibility, and consistency related altogether to understudy fulfillment. steady with the previously mentioned examinations the resulting speculations are defined.

H5: Involvement is a significant and positive relationship with job satisfaction.

H6: Consistency is a significant and positive relationship with job satisfaction.

H7: Adaptability is a significant and positive relationship with job satisfaction.

H8: Mission is a significant and positive relationship with job satisfaction.

Job satisfaction and organizational performance

Some of the scientists have discovered that there's a positive connection between work fulfillment and authoritative execution (Melián-gonzález and Bulchand-gidumal, 2015; Pang and Lu, 2018; Zeffane and Bani Melhem, 2017). Latif et al., (2013)argued that fulfilled workers are a high activity entertainer inside the association. As indicated by Melián-gonzález et al., (2015) representatives who distinguish an association's activities toward them as accommodating are highlighted by good methodologies and should feel obliged to answer and have the enthusiasm to apply increasingly more exertion at the working environment. it's obvious from the sooner research decidedly anticipated occupation fulfillment. Bashir et al., (2013)recommended that probably the most purpose behind the disappointment of this presentation of the laborers in banks is that the lacking of having some expertise in worker work fulfillment inside the association. As indicated by Pawirosumarto et al., (2017) workplace, administration style, authoritative culture, and occupation fulfillment with the presentation of representatives are basic for their positive effect.M.A. Sanda and Kuada, (2016)concluded in his examination authoritative culture has an impact on execution and occupation fulfillment, particularly banking organizations' exhibition and representative activity fulfillment are improved when the way of life is predicated on advancement, motivations, and good work conditions. Likewise, it is frequently unsurprising that worker work fulfillment with hierarchical culture can assume a critical function in expanding inspiration and performance(Karyotakis and Moustakis, 2016). There's an outsized measure of writing that fulfilled hierarchical workers with an authoritative culture that has more elevated levels of execution than those that are less satisfied(Awan et that those banks that have a significant level of representative fulfillment are discovered to be more entertainers in their organizations(Ghafoor Awan and Asghar, 2014). Additionally,Awan et al., (2014) announce that representative employment fulfillment is decidedly corresponded with authoritative execution. Discoveries are made on the rationale based that when representatives are happy with their activity inside the association they are more persuaded and objective situated at that point eventually increment authoritative execution. The ensuing theory has been outlined by the researcher upheld the above past examinations

H9: Job satisfaction is a positive and significant relationship with organizational performance.

\section{Mediating effect of job satisfaction}

A few bits of examination have likewise been connected to hierarchical culture with authoritative execution (Yildı, 2014; Nikpour, 2017; Uzkurt, Kumar, Semih Kimzan, et al., 2013)and additionally indicating that hierarchical culture includes a positive and noteworthy impact on the hierarchical exhibition. Besides, authoritative culture has been concentrated during a relationship with work fulfillment by different analysts (Chipunza and Malo, 2017; Sami et al., 2011) and perceived that hierarchical culture has essentially and

al., 2014). Discoveries are established on the basis that if authoritative culture particularly in banking foundations are reasonable, worker arranged, staff inclusion inside the hierarchical choosing, consistency in business measure, effectively inner change in light of outside conditions, and alsoa clear hierarchical mission. There's no vulnerability that financial representatives will be happy with the hierarchical culture and get inspired to answer regarding singular exhibitions likewise as authoritative execution. The ensuing speculations are set up on the lower part of the above-indicated literatureAccordingly, we recommend that activity fulfillment assumes an interceding function on the connection between dimenssions of hierarchical culture, inclusion culture, consistency culture, flexibility culture and mission culture withorganizational execution. Consequently, in the light of the above observation, we propose the accompanying theories

H10: Job satisfaction mediates the relationship between involvement culture and organizational performance.

H11: Job satisfaction mediates the relationship 
between consistency culture and organizational performance.

H12: Job satisfaction mediates the relationship between adaptability culture and organizational performance.

H13: Job satisfaction mediates the relationship between mission culture and organizational performance.

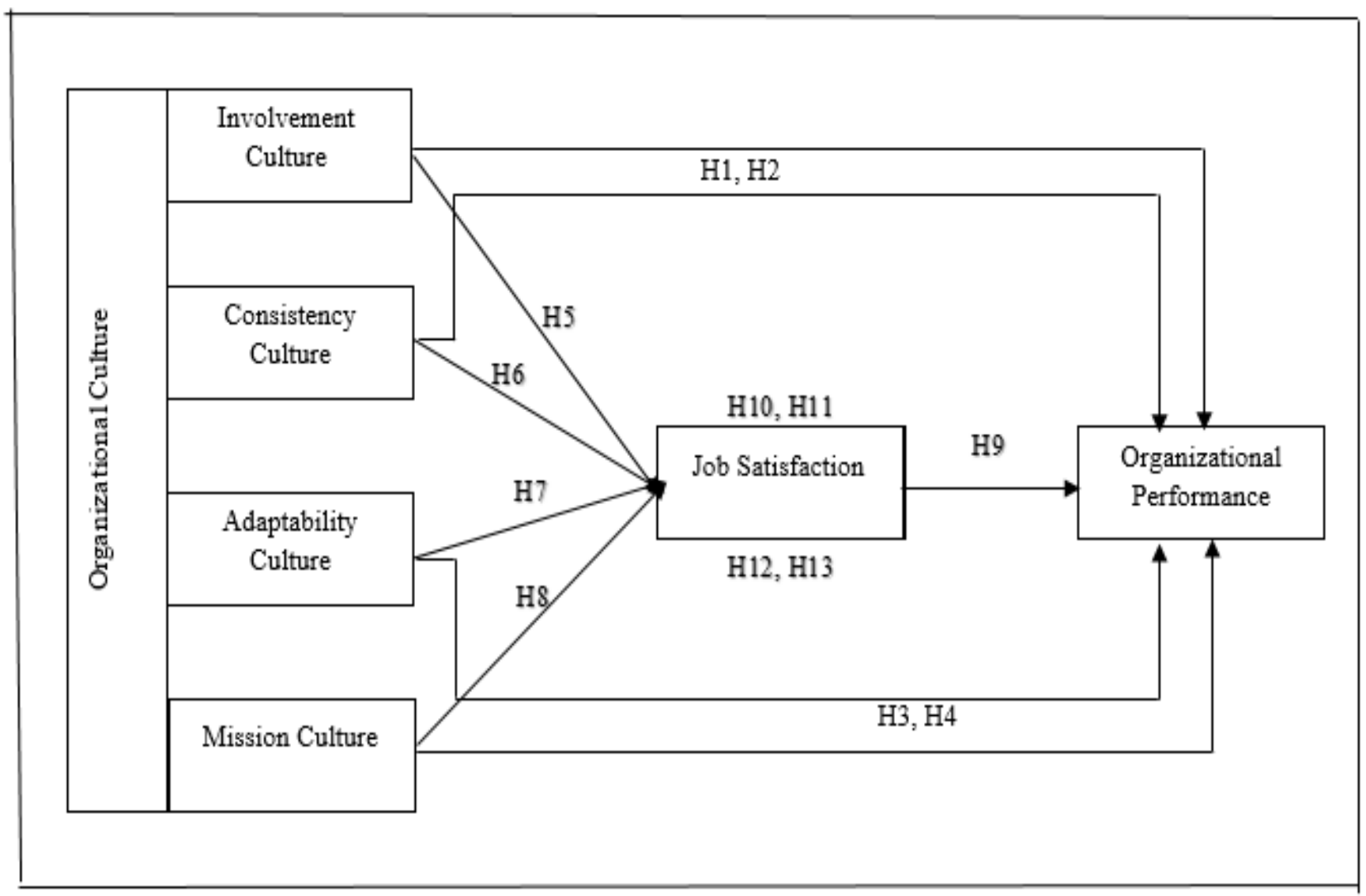

Figure 1: Research framework of the Study

\subsection{Research Methodology}

\subsection{Data collection}

This investigation has focused on Pakistan's financial area. It incorporates eight public banks situated in Punjab and Sindh, two territories of Pakistan. The information were gathered haphazardly from 450 respondents from eight public banks including the National Bank of Pakistan (NBP), First Woman Bank (FWBL), The Bank of Punjab (BOP), The Bank of Khyber (BOK), Sindh Bank Limited (SNDB), SME Bank Limited, Industrial Development Bank of Pakistan (IDBP) and Zarai Taraqiati Bank Limited (ZTBL). Banks were chosen dependent on the accessibility and legitimacy of the information. Printed copies of the survey were conveyed to the respondent. The upside of gathering and dispersing polls is that you have some an ideal opportunity to check the responses to the disseminated things (Saunders, Lewis and Thornhill, 2015), which can build the unwavering quality of your information. Thus, 320 polls were gathered from 450 after rehashed visits(Shahbaz, Shaikh, Qureshi, Jamali, and Sohu, 2019). The main role of disseminating 450 surveys to the objective populace is to meet the base example size required and increment the reaction rate. The reaction rate can be expanded in two different ways, to be specific, the attention on the respondent and the dissemination of the thing (Alreck and settle, 2004). Analysts appropriated 450 surveys to bank office chiefs of eight public banks in Punjab and Sindh, Pakistan. 334 surveys were returned by the respondents which are $74 \%$ of the aggregate. Thus, 14 surveys were barred because of missing information. The last volume of usable surveys was 320 with a $71 \%$ reaction rate that was utilized for additional examination. Up to half of reactions are adequate in business and social examination (Saunders et al., 2015).

Specialists utilized t-tests to look at the contrasts among right on time and late respondents(Naqshbandi, Garib Singh, and Ma, 2016). In this investigation, the specialist has taken proportionate delineated examining to affirm proportionate portrayal of both 
male and female brokers of each chosen bank under a lot of branch supervisor (BM), provincial administrator (RM), operational director (OM) and partner branch chief (ABM). The specialist has chosen a whole of 253 male and 67 female financiers including 94 branch directors, 45 local supervisors, 56 operational administrators, 58 right hand chiefs and 67 female brokers including 15 branch administrator, 17 territorial administrators, 16 operational administrators, 19 partner branch director perceived on their extent in the objective populace of the current examination.

The example has been chosen from each and every bank dependent on their proportion in the objective populace, for example 82 from the National bank of Pakistan, trailed by 17 from first ladies bank, 63 from The Bank of Punjab, 13 from The Bank of Khyber, 51 from Sindh bank restricted, 6 from SME bank restricted, 24 from Industrial improvement bank restricted and in the last 64 from Zarai Tarqiati bank limited. Relevant data with respect to the segment proof of the respondents is introduced in Table 1. Sex conveyance indicated that around 79 percent of the representatives were guys and 21 percent were females. Be that as it may, this segment information created was from the public bank of two regions of Pakistan. Age 34\% are between 25-35, the greater part of the respondents were seen between the age of 36-45 having an extent of 39\%, 24.\% respondents recorded at the age of 46-55, while just $3 \%$ were found in the age of 56 or more. The outcome likewise shows that more than around 76 percent of the respondents were hitched and 24 were unmarried. Despite the fact that in excess of 92 percent of the respondents have a Master's and four year college educations and eight percent of representatives were the money related confirmation or degree. As indicated by the accessible data about employment positions in broad daylight bank office supervisor, Assistant branch administrators were having an extent of 34, 24 recorded as provincial chief and $19 \%$ recorded as operational director $23 \%$. Furthermore, 24 of the bank representatives had encountered between 1-5 years. While the remainder of the financial experience was found as $32 \%$ between 6-10 years, $30 \%$ as more than $11-15$ years and $14 \%$ over 16 years.

Table 1: Demographic respondents

\begin{tabular}{|l|l|l|l|l|}
\hline $\begin{array}{l}\text { S. } \\
\mathrm{N}\end{array}$ & \multicolumn{2}{|l|}{ Attributes } & $\begin{array}{l}\text { Frequenc } \\
\mathrm{y}\end{array}$ & $\begin{array}{l}\text { Percentag } \\
\mathrm{e}\end{array}$ \\
\hline 1 & \multirow{2}{*}{ Gender } & Male & 253 & 79 \\
\cline { 3 - 5 } & & Female & 67 & 21 \\
\hline 2 & Age & $\begin{array}{l}25-35 \\
\text { years }\end{array}$ & 107 & 34 \\
\hline
\end{tabular}

\begin{tabular}{|c|c|c|c|c|}
\hline & & $\begin{array}{l}36-45 \\
\text { years }\end{array}$ & 126 & 39 \\
\hline & & $\begin{array}{l}46-55 \\
\text { years }\end{array}$ & 78 & 24 \\
\hline & & 56 - above & 9 & 3 \\
\hline \multirow[t]{2}{*}{3} & \multirow{2}{*}{$\begin{array}{l}\text { Marital } \\
\text { Status }\end{array}$} & Married & 244 & 76 \\
\hline & & Single & 76 & 24 \\
\hline \multirow[t]{3}{*}{4} & \multirow{3}{*}{$\begin{array}{l}\text { Highest } \\
\text { Level of } \\
\text { education }\end{array}$} & $\begin{array}{l}\text { Diploma, } \\
\text { Course }\end{array}$ & 27 & 8 \\
\hline & & Bachelor & 105 & 33 \\
\hline & & Master & 188 & 59 \\
\hline \multirow[t]{4}{*}{5} & \multirow[t]{4}{*}{$\begin{array}{l}\text { Job } \\
\text { position }\end{array}$} & $\begin{array}{l}\text { Branch } \\
\text { manager }\end{array}$ & 109 & 34 \\
\hline & & $\begin{array}{l}\text { Regional } \\
\text { manager }\end{array}$ & 62 & 19 \\
\hline & & $\begin{array}{l}\text { Operational } \\
\text { manager }\end{array}$ & 72 & 23 \\
\hline & & $\begin{array}{l}\text { Assistant } \\
\text { manager }\end{array}$ & 77 & 24 \\
\hline \multirow[t]{4}{*}{6} & \multirow{4}{*}{$\begin{array}{l}\text { Working } \\
\text { experienc } \\
\text { e }\end{array}$} & $1-5$ years & 77 & 24 \\
\hline & & $6-10$ years & 103 & 32 \\
\hline & & $\begin{array}{l}11-15 \\
\text { years }\end{array}$ & 96 & 30 \\
\hline & & $\begin{array}{l}16-\text { above } \\
\text { year }\end{array}$ & 44 & 14 \\
\hline \multirow[t]{8}{*}{7} & \multirow{8}{*}{$\begin{array}{l}\text { Name of } \\
\text { the bank } \\
\text { where } \\
\text { you are } \\
\text { working }\end{array}$} & $\begin{array}{l}\text { National } \\
\text { bank of } \\
\text { Pakistan }\end{array}$ & 82 & 26 \\
\hline & & $\begin{array}{l}\text { First women } \\
\text { bank limited }\end{array}$ & 17 & 5 \\
\hline & & $\begin{array}{l}\text { The bank of } \\
\text { Punjab }\end{array}$ & 63 & 20 \\
\hline & & $\begin{array}{l}\text { The bank of } \\
\text { Khyber }\end{array}$ & 13 & 4 \\
\hline & & $\begin{array}{l}\text { Sindh bank } \\
\text { limited }\end{array}$ & 51 & 16 \\
\hline & & SME bank & 6 & 2 \\
\hline & & $\begin{array}{l}\text { Industrial } \\
\text { developmen } \\
\mathrm{t} \text { bank of } \\
\text { Pakistan } \\
\end{array}$ & 24 & 7 \\
\hline & & $\begin{array}{l}\text { ZaraiTaraqia } \\
\text { ti Bank } \\
\text { Limited }\end{array}$ & 64 & 20 \\
\hline
\end{tabular}

\section{Measures}

For this investigation, information was gathered through polls. All surveys were upheld by a Likert scale beginning at 1 to 5, with Cronbach Alpha very 0.70 . This system centers around hierarchical culture measurements, contribution culture, consistency culture, versatility culture, and mission culture, and employment fulfillment as an intervention. there have been 35 things through and through the polls. the 
essential poll comprised of a total of 12 requests to survey the components of hierarchical culture and comprised of three things of each measurement and correspondingly the subsequent poll was to audit the exhibition of banks which had a total of seven things. Banking execution was appraised. In two kinds, productivity and adequacy; Performance incorporates 4 things and viability incorporates 3 things. There are 4 perspectives to work fulfillment which incorporate compensation, advancement, oversight, and nature of work, every angle incorporates 4 things. The information is investigated utilizing Smart PLS 3.2.9.

Table 2: Dimensions of organizational culture, job satisfaction and organizational performance with included items

\begin{tabular}{|c|c|c|c|c|}
\hline No. & Variable & Dimensions & $\begin{array}{l}\text { Number } \\
\text { of items }\end{array}$ & Source \\
\hline \multirow{4}{*}{1} & \multirow{4}{*}{$\begin{array}{c}\text { Organizational } \\
\text { Culture }\end{array}$} & $\begin{array}{c}\text { Involvement } \\
\text { culture }\end{array}$ & 3 & \multirow[t]{4}{*}{$\begin{array}{l}\text { Fey and } \\
\text { Denison } \\
(2003)\end{array}$} \\
\hline & & $\begin{array}{c}\text { Consistency } \\
\text { culture }\end{array}$ & 3 & \\
\hline & & $\begin{array}{c}\text { Adaptability } \\
\text { culture }\end{array}$ & 3 & \\
\hline & & $\begin{array}{l}\text { Mission } \\
\text { culture }\end{array}$ & 3 & \\
\hline \multirow{2}{*}{2} & \multirow{2}{*}{$\begin{array}{l}\text { Organizational } \\
\text { Performance }\end{array}$} & Efficiency & 4 & \multirow[t]{2}{*}{ Song, (2016) } \\
\hline & & Effectiveness & 3 & \\
\hline \multirow{4}{*}{3} & \multirow{4}{*}{$\begin{array}{c}\text { Job } \\
\text { Satisfaction }\end{array}$} & $\begin{array}{c}\text { Nature of } \\
\text { work }\end{array}$ & 4 & \multirow{4}{*}{$\begin{array}{l}\text { Dimitrios } \\
\text { Belias, } \\
\text { Athanasios } \\
\text { Koustelios, } \\
\text { George }\end{array}$} \\
\hline & & Pay & 4 & \\
\hline & & Promotion & 4 & \\
\hline & & Supervision & 4 & \\
\hline
\end{tabular}

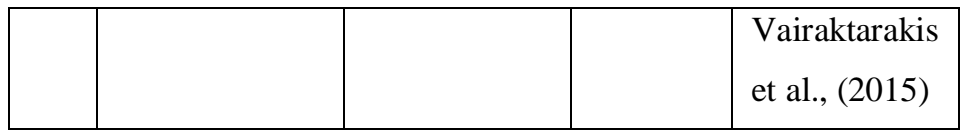

\section{Data analysis}

SmartPLS 3.2.9 was applied to data analysis using two steps. The primary step was to analyze the measurement model to make sure reliability, convergent, and discriminant validity. Within the second step, the structural model was analyzed to determine the connection between the constructs (Götz et al., 2010).

\section{Reliability assessment}

This investigation inspects the dependability, focalized, and discriminant legitimacy of factors. As indicated by Henseler et al., (2009) Fornell and Larcker, (1981) rules, the value of normal fluctuation separated (AVE) ought to be very 0.5 (AVE > 0.5) to ensure united legitimacy (Table 3). According to Hair et al., (2014)values of composite unwavering quality 0.70 and 0.90 are viewed as palatable for corroborative examinations or more 0.60 and 0.70 Cronbach alpha qualities are viewed as suitable in exploratory investigations. During this examination for dependability, both Cronbach alpha and composite unwavering quality are utilized.

To gauge the uniqueness of the develops this examination likewise evaluated the discriminant legitimacy of the auxiliary condition displaying. According to Fornell and Larcker (1981) models, the square of the Average Variance Extracted (AVE) ought to be a remarkable bury builds relationship (Table 4).

Table 3: Reliability and convergent validity

\begin{tabular}{|l|l|l|l|}
\hline Constructs & $\begin{array}{l}\text { Cronbach's } \\
\text { Alpha }\end{array}$ & $\begin{array}{l}\text { Composite } \\
\text { Reliability }\end{array}$ & $\begin{array}{l}\text { Average } \\
\text { Variance } \\
\text { Extracted } \\
\text { (AVE) }\end{array}$ \\
\hline Adaptability Culture & 0.90 & 0.94 & 0.84 \\
\hline Consistency Culture & 0.90 & 0.94 & 0.83 \\
\hline
\end{tabular}




\begin{tabular}{|l|l|l|l|}
\hline Involvement Culture & 0.84 & 0.90 & 0.76 \\
\hline Jab Satisfaction & 0.92 & 0.93 & 0.45 \\
\hline Mission Culture & 0.79 & 0.88 & 0.70 \\
\hline Organizational Performance & 0.87 & 0.90 & 0.58 \\
\hline
\end{tabular}

Table 4: Fornell-Larcker Criterion

\begin{tabular}{|c|c|c|c|c|c|c|c|c|c|c|}
\hline Constructs & $\begin{array}{l}\text { Adap. } \\
\text { Culture }\end{array}$ & $\begin{array}{l}\text { Consis. } \\
\text { Culture }\end{array}$ & Effect. & Effici. & $\begin{array}{l}\text { Involv. } \\
\text { Culture }\end{array}$ & $\begin{array}{l}\text { Miss. } \\
\text { Culture }\end{array}$ & $\begin{array}{l}\text { Nature } \\
\text { of } \\
\text { Work }\end{array}$ & Pay & Prom. & Super. \\
\hline $\begin{array}{l}\text { Adaptability } \\
\text { Culture }\end{array}$ & 0.916 & & & & & & & & & \\
\hline $\begin{array}{l}\text { Consistency } \\
\text { Culture }\end{array}$ & 0.588 & 0.910 & & & & & & & & \\
\hline Effectiveness & 0.792 & 0.469 & 0.905 & & & & & & & \\
\hline Efficiency & 0.708 & 0.396 & 0.680 & 0.775 & & & & & & \\
\hline $\begin{array}{l}\text { Involvement } \\
\text { Culture }\end{array}$ & 0.218 & 0.115 & 0.189 & 0.287 & 0.872 & & & & & \\
\hline $\begin{array}{l}\text { Mission } \\
\text { Culture }\end{array}$ & 0.664 & 0.389 & 0.542 & 0.616 & 0.296 & 0.839 & & & & \\
\hline $\begin{array}{l}\text { Nature of } \\
\text { Work }\end{array}$ & 0.409 & 0.227 & 0.324 & 0.449 & 0.420 & 0.476 & 0.832 & & & \\
\hline Pay & 0.355 & 0.091 & 0.428 & 0.429 & 0.375 & 0.382 & 0.550 & 0.806 & & \\
\hline Promotion & 0.351 & 0.089 & 0.254 & 0.381 & 0.473 & 0.469 & 0.680 & 0.541 & 0.876 & \\
\hline Supervision & 0.461 & 0.163 & 0.520 & 0.521 & 0.440 & 0.535 & 0.542 & 0.579 & 0.563 & 0.743 \\
\hline
\end{tabular}

\subsection{Structural model}

importance (Q2), impact sizes (f2), and coefficient of assurance (R2). Beta qualities are estimated dependent on their greatness sign. The acceptable incentive for way coefficient greatness is between -1 to +1 . The way coefficient esteems happening near the +1 indicate a solid positive relationship. While on the contrary hand, the one near - 1 speaks to a solid negative relationship.

The auxiliary model speaks to an aspect of the relapse of the model and shows the association between the idle develops of the common investigation. As per Byrne (1998) structure model demonstrates the immediate or backhanded change inside the estimations of the inverse dormant factors. The fundamental measurements of the structure model are the criticalness of the way coefficient; the prescient

Table 3: Reliability and convergent validity

\begin{tabular}{|l|l|l|l|}
\hline Constructs & $\begin{array}{l}\text { Cronbach's } \\
\text { Alpha }\end{array}$ & $\begin{array}{l}\text { Composite } \\
\text { Reliability }\end{array}$ & $\begin{array}{l}\text { Average } \\
\text { Variance } \\
\text { Extracted } \\
\text { (AVE) }\end{array}$ \\
\hline Adaptability Culture & 0.90 & 0.94 & 0.84 \\
\hline Consistency Culture & 0.90 & 0.94 & 0.83 \\
\hline Involvement Culture & 0.84 & 0.90 & 0.76 \\
\hline Jab Satisfaction & 0.92 & 0.93 & 0.45 \\
\hline
\end{tabular}




\begin{tabular}{|l|l|l|l|}
\hline Mission Culture & 0.79 & 0.88 & 0.70 \\
\hline Organizational Performance & 0.87 & 0.90 & 0.58 \\
\hline
\end{tabular}

Table 4: Fornell-Larcker Criterion

\begin{tabular}{|c|c|c|c|c|c|c|c|c|c|c|}
\hline Constructs & $\begin{array}{l}\text { Adap. } \\
\text { Culture }\end{array}$ & $\begin{array}{l}\text { Consis. } \\
\text { Culture }\end{array}$ & Effect. & Effici. & $\begin{array}{l}\text { Involv. } \\
\text { Culture }\end{array}$ & $\begin{array}{l}\text { Miss. } \\
\text { Culture }\end{array}$ & $\begin{array}{l}\text { Nature } \\
\text { of } \\
\text { Work }\end{array}$ & Pay & Prom. & Super. \\
\hline $\begin{array}{l}\text { Adaptability } \\
\text { Culture }\end{array}$ & 0.916 & & & & & & & & & \\
\hline $\begin{array}{l}\text { Consistency } \\
\text { Culture }\end{array}$ & 0.588 & 0.910 & & & & & & & & \\
\hline Effectiveness & 0.792 & 0.469 & 0.905 & & & & & & & \\
\hline Efficiency & 0.708 & 0.396 & 0.680 & 0.775 & & & & & & \\
\hline $\begin{array}{l}\text { Involvement } \\
\text { Culture }\end{array}$ & 0.218 & 0.115 & 0.189 & 0.287 & 0.872 & & & & & \\
\hline $\begin{array}{l}\text { Mission } \\
\text { Culture }\end{array}$ & 0.664 & 0.389 & 0.542 & 0.616 & 0.296 & 0.839 & & & & \\
\hline $\begin{array}{l}\text { Nature of } \\
\text { Work }\end{array}$ & 0.409 & 0.227 & 0.324 & 0.449 & 0.420 & 0.476 & 0.832 & & & \\
\hline Pay & 0.355 & 0.091 & 0.428 & 0.429 & 0.375 & 0.382 & 0.550 & 0.806 & & \\
\hline Promotion & 0.351 & 0.089 & 0.254 & 0.381 & 0.473 & 0.469 & 0.680 & 0.541 & 0.876 & \\
\hline Supervision & 0.461 & 0.163 & 0.520 & 0.521 & 0.440 & 0.535 & 0.542 & 0.579 & 0.563 & 0.743 \\
\hline
\end{tabular}

\subsection{Structural model}

The auxiliary model speaks to an aspect of the relapse of the model and shows the association between the idle develops of the common investigation. As per Byrne (1998) structure model demonstrates the immediate or backhanded change inside the estimations of the inverse dormant factors. The fundamental measurements of the structure model are

the criticalness of the way coefficient; the prescient importance (Q2), impact sizes (f2), and coefficient of assurance (R2). Beta qualities are estimated dependent on their greatness sign. The acceptable incentive for way coefficient greatness is between -1 to +1 . The way coefficient esteems happening near the +1 indicate a solid positive relationship. While on the contrary hand, the one near - 1 speaks to a solid negative relationship.

Table 5: Results of the structural model analysis ( $\beta$-value and t-value)

\begin{tabular}{|l|l|l|l|l|l|}
\hline Relationship of variable & $\begin{array}{l}\beta- \\
\text { value }\end{array}$ & $\begin{array}{l}\text { Standard } \\
\text { Deviation }\end{array}$ & t-value & $\begin{array}{l}\text { P- } \\
\text { Values }\end{array}$ & $\mathrm{F}^{2}$ \\
\hline $\begin{array}{l}\text { Adaptability Culture -> Jab } \\
\text { Satisfaction }\end{array}$ & 0.259 & 0.068 & 3.812 & 0.000 & 0.056 \\
\hline $\begin{array}{l}\text { Adaptability Culture -> } \\
\text { Organizational Performance }\end{array}$ & 0.723 & 0.046 & 15.580 & 0.000 & 0.635 \\
\hline $\begin{array}{l}\text { Consistency Culture -> Jab } \\
\text { Satisfaction }\end{array}$ & -0.152 & 0.043 & 3.552 & 0.000 & 0.029 \\
\hline Consistency Culture -> & -0.012 & 0.037 & 0.324 & 0.746 & 0.000 \\
\hline
\end{tabular}




\begin{tabular}{|l|l|l|l|l|l|}
\hline Organizational Performance & & & & & \\
\hline $\begin{array}{l}\text { Involvement Culture -> Jab } \\
\text { Satisfaction }\end{array}$ & 0.376 & 0.047 & 7.995 & 0.000 & 0.251 \\
\hline $\begin{array}{l}\text { Involvement Culture -> } \\
\text { Organizational Performance }\end{array}$ & 0.061 & 0.026 & 2.325 & 0.020 & 0.000 \\
\hline $\begin{array}{l}\text { Jab Satisfaction -> Organizational } \\
\text { Performance }\end{array}$ & 0.168 & 0.045 & 3.733 & 0.000 & 0.048 \\
\hline Mission Culture -> Jab Satisfaction & 0.342 & 0.065 & 5.242 & 0.000 & 0.122 \\
\hline $\begin{array}{l}\text { Mission Culture -> Organizational } \\
\text { Performance }\end{array}$ & 0.137 & 0.042 & 3.278 & 0.001 & 0.010 \\
\hline
\end{tabular}

The examination found a solid negative relationship with consistency culture to work fulfillment and hierarchical execution, no negative relationship was found aside from these two referenced builds. Inside a similar way, its noteworthiness level is examined on premise of t-value(J. F. J. Hair et al., 2014). The expressed t-esteem for the way coefficient to be noteworthy is 1.96 (J. F. J. Hair et al., 2014). In any case, as introduced in the above Table 5 that the consistency culture with hierarchical execution havea beta worth -0.012 , t-esteem $=0.324$ was saw negative relationship andinsignificant impact in this investigation, whileconsistency culture with work fulfillment beta worth is -0.152 , t-esteem is 3.552 shows that negetive relationship yet critical effect.Adaptability culture with authoritative execution beta worth 0.723 , t-esteem $=15.580$ shows solid impact and positive relationship on authoritative execution just as in regards to versatility culture, with work fulfillment having beta worth 0.259 , t-esteem $=$ 3.812, association culture with work fulfillment, invovement culture with authoritative execution, work fulfillment with authoritative execution, mission culture with work fulfillment, mission culture with authoritative execution have positive and noteworthy relationship, having beta worth, $0.376,0.061,0.342$, 0.137 and t-esteem is $7.995,2.325,3.733,5.242$, 3.278 .

\subsection{Coefficient of determination (R2) value}

The estimation of R2 is somewhere in the range of 0 and 1, with high qualities that demonstrate a greatest illustrative force. R2 estimations of $0.75,0.50$ and 0.25 are viewed as considerable, moderate, and feeble. The worthy furthest reaches of R2 esteems isdepend onsituation and when a R2 esteem under 0.10 is viewed as good. While, concurring toChin, (2010) R2 esteems $0.67,0.33$ and 0.19 for subordinate factors and these qualities are considered as significant, moderateand powerless. Table 6 R2 esteem uncovered for work fulfillment is 0.485 (moderate) and connotes a $48 \%$ change in work fulfillment is portrayed through inclusion culture, consistency culture, flexibility culture and mission culture. While, R2 esteem expressed for hierarchical execution is 0.703 (considerable) and shows that $70 \%$ change is started through contribution culture, consistency culture, versatility culture and mission culture.

Table 6: R-square values

\begin{tabular}{|l|l|}
\hline Endogenous constructs & $\mathrm{R}^{2}$ \\
\hline Job Satisfaction & 0.485 \\
\hline Organizational Performance & 0.703 \\
\hline
\end{tabular}

\subsection{Predictive relevance $(Q 2)$}

The Q2 esteem depends on a blindfolding strategy that eliminates a point in the information ascribes the erased focuses alongside the mean and gauges model specifications(Sarstedt, Ringle, Henseler, and Hair, 2014). The estimations of Q2 for a specific endogenous develop must be more prominent than zero to show the prescient exactness of the auxiliary model for this build. As indicated by Joseph F. Hair et al., (2019)Q2 more noteworthy than $0,0.25$ and 0.50 portrays little, medium and huge prescient pertinence of the model. In Table 7 the Q2 estimation of employment fulfillment is 0.239 (little) and the Q2 estimation of hierarchical execution is 0.384 (medium).

\section{Table 7: Predictive relevance Q2}

\begin{tabular}{|l|l|}
\hline endogenous construct & $\mathrm{Q}^{2}$ \\
\hline Job satisfaction & 0.239 \\
\hline Organizational performance & 0.384 \\
\hline
\end{tabular}

\subsection{Mediation analysis}

In this investigation, work fulfillment develops as a middle person on the relationship of contribution culture, consistency culture, versatility culture and mission culture. The intervention investigation was led through PLS-SEM by utilizing the bootstrapping strategy. The utilization of bootstrapping helps to test the intervention speculations (Edwards et al., 2016). This strategy produces $95 \%$ certainty stretches for the go betweens. Allude to Table 7 for the synopsis of 
theories surveyed through the interceding impact of employment fulfillment.

Table 7: Mediation analysis

\begin{tabular}{|l|l|l|l|l|}
\hline Relationship of hypotheses & $\beta$-value & $\begin{array}{l}\text { Standard } \\
\text { Deviation }\end{array}$ & t-value & P-Values \\
\hline $\begin{array}{l}\text { Adaptability Culture -> Jab } \\
\text { Satisfaction -> Organizational } \\
\text { Performance }\end{array}$ & 0.043 & 0.018 & 2.484 & 0.013 \\
\hline $\begin{array}{l}\text { Consistency Culture -> Jab } \\
\text { Satisfaction -> Organizational } \\
\text { Performance }\end{array}$ & -0.026 & 0.010 & 2.664 & 0.008 \\
\hline $\begin{array}{l}\text { Involvement Culture -> Jab } \\
\text { Satisfaction -> Organizational } \\
\text { Performance }\end{array}$ & 0.063 & 0.019 & 3.255 & 0.001 \\
\hline $\begin{array}{l}\text { Mission Culture -> Jab Satisfaction -> } \\
\text { Organizational Performance }\end{array}$ & 0.057 & 0.018 & 3.150 & 0.002 \\
\hline
\end{tabular}

Versatility culture to work fulfillment has a $\beta$ estimation of 0.043 and was discovered huge, t-esteem $=2.484$, trailed by the $\beta$-estimation of consistency culture to work fulfillment was inspected $\beta$-esteem as 0.026 was found adversely intervened on the connection among build and discovered huge with testeem $=2.664$, also, the aftereffects of association culture to work fulfillment $\beta$-esteem is 0.063 and $\mathrm{t}$ esteem is 3.255 , discovered positive and critical mediation. And finally,mission culture to work fulfillment has a $\beta$-esteem is 0.057 that was discovered positive and huge with a t-esteem $=3.150$. Therefore, these outcomes uphold the keyhypothesis of this examination that activity fulfillment has an intervening function in the connection between measurements of authoritative culture, contribution culture, consistency culture, versatility culture and mission culture with hierarchical execution. Henceforth, H10, H12, and $\mathrm{H} 13$ are upheld. We can likewise presume that H11job fulfillment is negativelymediatedwhich is additionally noteworthy in the connection between consistency culture and hierarchical execution. The consequences of thisstudy additionally show that activity fulfillment portrays a lot of fluctuation in authoritative execution.

\section{Discussion and conclusion}

Employment fulfillment has become a significant apparatus for associations to keep on performing great Organizations invest a ton of time, sources and fuel in building up a hierarchical culture that adds to a reliably decent presentation. This exploration contemplated the interceding function of employment fulfillment between the relationship of the elements of hierarchical culture, inclusion culture, consistency culture, versatility culture and mission culture with authoritative execution. The reason of this investigation was to support the intercession function of employment fulfillment in the association can be decidedly affected by the elements of hierarchical culture, which thusly would be related with in general authoritative performance.Our results will apply to the financial part in Pakistan. Notwithstanding, a survey of the writing recommends that outcomes may apply to the financial division in different societies also, albeit such exploration will require future examination.

\section{Testing $H 1, H 2, H 3, H 4$}

$\mathrm{H} 1, \mathrm{H} 2, \mathrm{H} 3, \mathrm{H} 4$ proposed a positive connection between inclusion culture, consistency culture, flexibility culture and mission culture with authoritative execution. This was tried while testing the SmartPLS 3.2.9. It very well may be seen from Table 5 that inclusion culture, flexibility culture and mission culture has a huge positive effect on authoritative execution $(\beta=0.061, \beta=0.723, \beta=$ $0.137, \mathrm{p}<0.020, \mathrm{p}<0.000, \mathrm{p}<0.001)$ with t-esteem 2.325, t - esteem 15.580, t - esteem 3.278. Subsequently, H1, H3, and H4are affirmed and inclusion culture, flexibility culture and mission culture have a huge positive effect on hierarchical execution. While,

consistency culture has an immaterial negative effect on authoritative execution $(\beta=-0.012, p<0.746)$ with $\mathrm{t}$ - esteem 0.324 .

\section{Testing H5, H6, $H 7$, $H 8$}

$\mathrm{H} 5, \mathrm{H} 6, \mathrm{H} 7, \mathrm{H} 8$ proposed a positive connection between inclusion culture, consistency culture, versatility culture and mission culture with work fulfillment. It tends to be seen from Table 5 that contribution culture, versatility culture and mission 
culture has a noteworthy positive effect on work fulfillment ( $\beta=0.376, \beta=0.259, \beta=0.342, p<0.000$, $\mathrm{p}<0.000, \mathrm{p}<0.001)$ with $\mathrm{t}$-esteem $7.995, \mathrm{t}$ - esteem 3.812, $\mathrm{t}$ - esteem 5.242. Henceforth, H5, H7, and H8 is affirmed and association culture, flexibility culture and mission culture have a huge positive effect on authoritative execution. While, consistency culture has a negative relationship and noteworthy effect on work fulfillment $(\beta=-0.152, \mathrm{p}<0.000)$ with $\mathrm{t}-$ esteem 0.3552 .

\section{Testing H9}

As referenced before, $\mathrm{H} 9$ expressed that activity fulfillment is decidedly and essentially identified with authoritative execution. At the point when tried during Smartpls 3.2.9, the outcomes affirm that, as can be found in Table 5 that activity fulfillment has a positive related and critical effect on hierarchical execution $(\beta$ $=0.168, \mathrm{p}<0.000$ ) with $\mathrm{t}$ - esteem 3.733 .

Testing H1O, H11, H12, H13

\section{Implications and limitations of the study}

This examination permits us to make key proposals for expanding hierarchical execution just as representative occupation satisfaction. Organizational supervisors can exploit the beneficial outcomes of the relationship we have closed between authoritative culture and employment satisfaction.Managers strive to improve the exhibition of their associations at all levels. The review utilized in this investigation shows that improving the hierarchical culture with the assistance of chiefs makes workers' positions more satisfactory. Organizations that perceive the uniqueness of their workers and hold fast to the vision of administrators for the most part perform better. The presence of such an atmosphere and culture supports and helps worker fulfillment. The aftereffects of this examination give significant understandings into associations attempting to counter change, particularly in the banking sector.The banking segment specifically has gone through certain changes, particularly in late years.The banking segment works in an exceptionally serious climate and accordingly, worker work fulfillment is extremely helpful for serious challenges.Traditionally, the financial division has been giving more consideration to innovation and it has been seen that authoritative culture has not been given a lot of need. This investigation utilized information from two territories of Pakistan and it has helped us to comprehend significant parts of Pakistan's authoritative climate. The authoritative atmosphere in Pakistan has changed a great deal and there is a solid
H10, H11, H12, H13predicted that activity satisfactionmediates the connection between inclusion culture, consistency culture, versatility culture and mission culture with hierarchical execution. As referenced before, inclusion culture, consistency culture, flexibility culture and mission culture has a critical positive effect on work fulfillment ( $\beta=0.063$, $\beta=-0.026, \beta=0.043, \beta=0.057, p<0.001, p<0.008$, $\mathrm{p}<0.013, \mathrm{p}<0.002$ ). Additionally, t-insights estimation of these speculations $(\mathrm{t}$ - esteem 3.255, $\mathrm{t}$ esteem 2.664, $\mathrm{t}$ - esteem 2.484, $\mathrm{t}$ - esteem 3.150). Consequently, H10, H12, and H13 are affirmed and employment fulfillment intercedes the connection between contribution culture, versatility culture and mission culture with hierarchical execution.

While H11 results work fulfillment is adversely interceded which is furthermore critical inside the connection between consistency culture and authoritative execution. The consequences of this examination likewise show that activity fulfillment clarifies a major measure of change in hierarchical execution.

understanding that they need to challenge in the financial part for fast development. Maybe along these lines, authoritative culture and the advancement of occupation fulfillment have been a high plan for the financial division in Pakistan. Therefore, supervisors will provoke systems to help advance occupation fulfillment and improve hierarchical execution. Consequently, as per our examination, worker work fulfillment and encouraging an authoritative culture just as supporting them will help Pakistan's public part banks increment their seriousness and hierarchical execution.

At long last, these discoveries have a few constraints as the examination was led with information from just two areas of Pakistan, Sindh and Punjab, and gathered information from eight public part banks as an example of the exploration. Accordingly, the consequences of this examination might be the most well-known in Pakistan's financial segment. Despite the fact that the investigation of our writing in this part urges us to assume that our outcomes will apply to some different nations settings and ventures, future examination will be estimated with information from different settings. Additionally, the bigger example size and more examination with various fields will permit the outcomes to be looked at so the relationship can be resolved clearly. Further examination may likewise analyze the impacts of different develops, for example, advancement, work execution, and duty on hierarchical execution. 
Reference

[1] Abubakre, M., Coombs, C., \& Ravishankar, M. N. N. (2014). The influence of organizational culture on the outcome of is implementation. Icis, December, 29-49.

[2] Ahmad, A. (2014). Performance Assessment of Private Organizations in Pakistan: A Case of Performance Assessment of Private Organizations in Pakistan: A Case of Selected Organizations of Rawalpindi / Islamabad. July.

[3] Akram, M. S., Goraya, M. A. S., Malik, A., \& Aljarallah, A. M. (2018). Organizational performance and sustainability: Exploring the roles of IT capabilities and knowledge management capabilities. Sustainability (Switzerland), $\quad$ 10(10). https://doi.org/10.3390/su10103816

[4] Shahbaz, M. S., Mubarik, M. S., Mubarak, M. F., \& Irshad, M. B. (2019). The Impact of Lean Practices on Educational Performance: An Empirical Investigation for Public Sector Universities of Malaysia. Journal of Independent Studies and Research-Management, Social Sciences and Economics, 17(2), 85-96.

[5] Al-Abdullat, B. M., \& Dababneh, A. (2018). The mediating effect of job satisfaction on the relationship between organizational culture and knowledge management in Jordanian banking sector. Benchmarking, 25(2), 517-544. https://doi.org/10.1108/BIJ-06-2016-0081

[6] Alreck, P. L., \& Settle, R. B. (2004). The Survey Research. Handbook (3 Ed.) New York: McGraw-Hill Irwin. Page-191.

[7] Shahbaz, M. S., Othman, B. A., Salman, P. M., Memon, D. A., \& Rasi, R. Z. B. R. (2020). A Proposed Conceptual Action Plan for
Identification, Assessment and Mitigation of Supply Chain Risks. Int. J. Advanced Operations Management, 12(1), 65-80.

[8] Arifeen, N., Hussain, M., Kazmi, S., Mubin, M., Mughal, S. L., \& Qadri, W. (2014). Measuring Business Performance: Comparison of Financial, Non Financial and Qualitative Indicators. Ssrn, 6(4), $38-45$. https://doi.org/10.2139/ssrn.2373145

[9] Awan, A. G., Asghar, I., Ghafoor Awan, A., \& Asghar, I. (2014). Impact of Employee Job Satisfaction on Their Performance... a Case Study of Banking Sector in Muzaffargarh District, Pakistan. Global Journal of Human Resource Management, 2(4), 71-94. https://doi.org/10.1017/CBO9781107415324.004

[10] Awuor, A. G. (2015). The Impact of Organizational Culture on Teacher Learning. Procedia - Social and Behavioral Sciences, 186, 1038-1044.

https://doi.org/10.1016/j.sbspro.2015.04.020

[11] Bandara, P. S. (2015). The Relationship between the Commercial Orientation, Organisational Culture and Social Performance of Community Finance Organisations in Victoria, Australia. August, 323. http://hdl.cqu.edu.au/10018/1039415

[12] Bashir, U., Sharma, R., Jauhari, S., Singh, V., Karunanithy, K., Ponnampalam, A., Dhankar, S., Vrinda, N. N., Jacob, N. A., Velnampy, P. T., Sivesan, S., Arif, M., Moeed, A., Corresponding, A., Ratnawat, R. G., Jha, P. C., Shahid, M. N., Polytechnic, O. S., Polytechnic, O. S., ... Naqvi, H. (2013). A study on the effect of Stress on performance of employees in Commercial Bank of Ceylon in the Eastern Province. Impact of Stress on Employees Job Performance A Study on Banking Sector of Pakistan, 5(2), 87-96. 
https://doi.org/0975-5853

[13] Belias, D., Koustelios, A., Vairaktarakis, G., \& Sdrolias, L. (2015). Organizational Culture and Job Satisfaction of Greek Banking Institutions. Procedia - Social and Behavioral Sciences, 175, 314-323.

https://doi.org/10.1016/j.sbspro.2015.01.1206

[14] Shahbaz, M. S., Shaikh, F. A., Qureshi, M. A., Jamali, Q. B., \& Sohu, S. (2019). The Influence of Supply Chain Collaboration on Supply Chain Performance for Malaysian Manufacturing Industry. Journal Of Organizational Behavior Research, 4(2), 203-218.

[15] Bellou, V. (2010). Organizational culture as a predictor of job satisfaction: The role of gender and age. Career Development International, $15(1)$ 4-19. https://doi.org/10.1108/13620431011020862

[16] Bhat, S. A., \& Beri, A. (2016). Development and validation of teachers perceived job performance scale (TPJP) in higher education. Man in India, 96(4), 935-944.

[17] Byrne, B. M. (1998). Structural equation modeling with LISREL. Prelis, and Simplis, 196199.

[18] Chatman, J. A., \& O'Reilly, C. A. (2016). Paradigm lost: Reinvigorating the study of organizational culture. Research in Organizational Behavior, 36, 199-224. https://doi.org/10.1016/j.riob.2016.11.004

[19] Cheema, A. M., \& Abbas, M. (2017). Organizational culture impact on banking performance in presence of organizational commitment: A case of banking sector of Pakistan. International Journal of Applied Business and Economic Research, 15(18), 67-83.

[20] Chienwattanasook, K., \& Jermsittiparsert, K. (2019). Influence of entrepreneurial orientation and total quality management on organizational performance of pharmaceutical SMEs in Thailand with moderating role of organizational learning. Systematic Reviews in Pharmacy, 10(2),

223-233.

https://doi.org/10.5530/srp.2019.2.31

[21] Chin, W. W. (2010). How to write up and report PLS analyses. In Handbook of partial least squares (pp. 655-690). Springer, Berlin, Heidelberg.

[22] Shahbaz, M. S., Soomro, A. B., Soomro, S., Sohu, S., \& Ahmed, B. (2020). The Role of Supply Chain Relationships in Risk Management by Enhancing Customer Satisfaction. International Journal of Disaster Recovery and Business Continuity, 11(1), 1756-1765.

[23] Chipunza, C., \& Malo, B. (2017). Organi Zational culture and job satisfaction among academic professionals at a South African university of technology. Problems and Perspectives in Management, 15(2), 148-161. https://doi.org/10.21511/ppm.15(2).2017.14

[24] Daniel R. Denison, A. k. M. (1995). A theory of organizational culture and effectiveness.pdf.

[25] Davoodalmousavi, S. M. (2013). The correlation between organizational culture and job satisfaction of employees in biotechnology production companies. Pelagia Research Library European Journal of Experimental Biology, 3(5), 389-399. www.pelagiaresearchlibrary.com

[26] Denison, D., Nieminen, L., \& Kotrba, L. (2014). Diagnosing organizational cultures: A conceptual and empirical review of culture effectiveness surveys. European Journal of Work and Organizational Psychology, 23(1), 145-161. https://doi.org/10.1080/1359432X.2012.713173

[27] Dimitrios Belias, Athanasios Koustelios, George Vairaktarakis, L. S., Belias, D., Koustelios, A., 
Vairaktarakis, G., Sdrolias, L., Dimitrios Belias, Athanasios Koustelios, George Vairaktarakis, L. S., Belias, D., Koustelios, A., Vairaktarakis, G., \& Sdrolias, L. (2015). Organizational Culture and Job Satisfaction of Greek Banking Institutions. Procedia - Social and Behavioral Sciences, $\quad$ 175, 314-323. https://doi.org/10.1016/j.sbspro.2015.01.1206

[28] Fey, C. F., \& Denison, D. R. (2003). Organizational Culture and Effectiveness: Can American Theory Be Applied in Russia? SSRN Electronic Journal, 598. https://doi.org/10.2139/ssrn.577141

[29] Fornell, C., \& Larcker, D. F. (1981). Structural equation models with unobservable variables and measurement error: Algebra and statistics. Journal of Marketing Research, 18(3), 328-388.

[30] Fu, W., \& Deshpande, S. P. (2014). The Impact of Caring Climate, Job Satisfaction, and Organizational Commitment on Job Performance of Employees in a China's Insurance Company. Journal of Business Ethics, 124(2), 339-349. https://doi.org/10.1007/s10551-013-1876-y

[31] Genc, E. (2017). STRATEGY IMPLEMENTATION ， ORGANIZATIONAL CULTURE AND PERFORMANCE IN TURKISH LOCAL GOVERNMENT BY ELIF GENC A Thesis Submitted in Fulfilment of the Requirements for the Degree of Doctor of Philosophy of Cardiff University Management , Employment and Organiz. December, 57.

[32] Ghafoor Awan, A., \& Asghar, I. (2014). Impact of Employee Job Satisfaction on Their Performance... a Case Study of Banking Sector in Muzaffargarh District, Pakistan. Global Journal of Human Resource Management, 2(4), 71-94. https://doi.org/10.1017/CBO9781107415324.004

[33] Gul, H., Usman, M., Liu, Y., Rehman, Z., \&
Jebran, K. (2018). Does the effect of power distance moderate the relation between person environment fit and job satisfaction leading to job performance? Evidence from Afghanistan and Pakistan. Future Business Journal, 4(1), 6883. https://doi.org/10.1016/j.fbj.2017.12.001

[34] Gyebi, A. D. (2016). THE EFFECTS OF ORGANIZATIONAL CULTURE ON ORGANIZATIONAL PERFORMANCE: A CASE STUDY OF ADEHYEMAN SAVINGS AND LOANS LIMITED A.

[35] Hair, Joe F., Sarstedt, M., Hopkins, L., \& Kuppelwieser, V. G. (2014). Partial least squares structural equation modeling (PLS-SEM): An emerging tool in business research. European Business Review, 26(2), 106-121. https://doi.org/10.1108/EBR-10-2013-0128

[36] Hair, Joseph F., Risher, J. J., Sarstedt, M., \& Ringle, C. M. (2019). When to use and how to report the results of PLS-SEM. European Business Review, 31(1), 2-24. https://doi.org/10.1108/EBR-11-2018-0203

[37] Hassan, M., \& Jagirani, T. S. (2019). Employee Turnover in Public Sector Banks of Pakistan. 14(1).

[38] Henseler, J., Ringle, C. M., \& Sinkovics, R. R. (2009). The use of partial least squares path modeling in international marketing. Advances in International Marketing, 20(May 2014), 277$319 . \quad$ https://doi.org/10.1108/S14747979(2009)0000020014

[39] Kanyurhi, E. B., \& Bugandwa Mungu Akonkwa, D. (2016). Internal marketing, employee job satisfaction, and perceived organizational performance in microfinance institutions. International Journal of Bank Marketing, 34(5), 773-796. https://doi.org/10.1108/IJBM-06-20150083 
[40] Karyotakis, K., \& Moustakis, V. (2016). Organizational factors, organizational culture, job satisfaction and entrepreneurial orientation in public administration. The European Journal of Applied Economics, 13(1), 47-59. https://doi.org/10.5937/ejae13-10781

[41] Kotrba, L. M., Gillespie, M. A., Schmidt, A. M., Smerek, R. E., Ritchie, S. A., \& Denison, D. R. (2012). Do consistent corporate cultures have better business performance? exploring the interaction effects. Human Relations, 65(2), 241262. https://doi.org/10.1177/0018726711426352

[42] Latif, M. S., Mushtaq, A., Muhammad, Q., Ferdoos, A., \& Hummayoun, N. (2013). Impact of employee' s job satisfaction on organizational performance . European Journal of Business and Management, 5(5), 166-171.

[43] Leskaj, E., Lipi, I., \& Ramaj, R. (2013). Features of Organizational Culture and Their Impact on Banking System Performance. International Journal of Economic Practices and Theories, 3(4), 288-293.

[44] Lund, D. B. (n.d.). organizational culture traits to job satisfaction.

[45] Mashal Ahmed, S. S. (2014). The Impact of Organizational Culture on Organizational Performance. Australian Journal of Basic and Applied Sciences, 7(14), 442-449.

[46] Melián-gonzález, S., \& Bulchand-gidumal, J. (2015). New evidence of the relationship between employee satisfaction and firm economic performance. https://doi.org/10.1108/PR-01-2014-0023

[47] Mohammed, O. K., \& Hammad, S. M. E. (2018). the Moderating Effect of Organizational. PhD Proposal, 18(2).

[48] Mousavi, S. A., Hosseini, S. Y., \& Hassanpour, N. (2015). On the Effects of Organizational
Culture on Organizational Performance: An Iranian Experience in State Bank Branches. on the effects of organizational culture on organizational performance: an iranian experience in state bank branches, 8(1), 97-116. https://doi.org/10.22059/ijms.2015.36617

[49] Muhammad Arifin, H. (2015). The influence of competence, motivation, and organisational culture to high school teacher job satisfaction and performance. International Education Studies. https://doi.org/10.5539/ies.v8n1p38

[50] Naqshbandi, M. M., Garib Singh, S. K., \& Ma, P. (2016). The link between organisational citizenship behaviours and open innovation: A case of Malaysian high-tech sector. IIMB Management Review, 28(4), 200-211. https://doi.org/10.1016/j.iimb.2016.08.008

[51] Nath Gangai, K., \& Agrawal, R. (2015). Job satisfaction and organizational commitment: Is it important for employee performance. International Journal of Management and Business Research, 5(4), 269-278.

[52] Nikpour, A. (2017). The impact of organizational culture on organizational performance: The mediating role of employee's organizational commitment. International Journal of Organizational Leadership, 6(1), 65-72. https://doi.org/10.33844/ijol.2017.60432

[53] Osabiya, B. J. (2015). The effect of employees motivation on organizational performance. Journal of Public Administration and Policy Research, $\quad 7(4), \quad 62-75$. https://doi.org/10.5897/jpapr2014.0300

[54] Pang, K., \& Lu, C. S. (2018). Organizational motivation, employee job satisfaction and organizational performance: An empirical study of container shipping companies in Taiwan. Maritime Business Review, 3(1), 36-52. 
https://doi.org/10.1108/MABR-03-2018-0007

[55] Partono Prasetio, A., Yuniarsih, T., \& Ahman, E. (2017). Job Satisfaction, Organizational Commitment, and Organizational Citizenship Behaviour in State-owned Banking. Universal Journal of Management, 5(1), 32-38. https://doi.org/10.13189/ujm.2017.050104

[56] Pawirosumarto, S., Setyadi, A., \& Khumaedi, E. (2017). The influence of organizational culture on the performance of employees at university of Mercu Buana. International Journal of Law and Management, 59(6). https://doi.org/10.1108/IJLMA-03-2016-0030

[57] Prajogo, D. I., \& McDermott, C. M. (2011). The relationship between multidimensional organizational culture and performance. International Journal of Operations and Production Management, 31(7), 712-735. https://doi.org/10.1108/01443571111144823

[58] Qazi, S., Miralam, M. S., \& Bhalla, P. (2017). Organizational culture and job satisfaction: A study of organized retail sector. Journal of Business and Retail Management Research, 12(1), 215-224.

[59] Rahman, H. (2014). Training and Job Satisfaction for Organizational Effectiveness: A Case Study from the Banking Sector. Central European Business Review, 3(1), 27-34. https://doi.org/10.18267/j.cebr.72

[60] Raju Uprety, S. B. C. (2014). College Culture and Student Satisfaction Raju Uprety* and Sabina Baniya Chhetri Kathmandu University School of Management, Lalitpur, Nepal. 4(1), 77-92.

[61] Sadighi, S. (2017). Anglia Ruskin University Organizational Culture and Performance: Research on SMEs at Tele-Healthcare Industry, United Kingdom Saeed Sadighi A Thesis in fulfilment of the Requirements of Anglia Ruskin University For the degree of Doctor of Philosophy Sub.

[62] Saira Yousaf, Madiha Latif, S. A. and A. S. (2012). Case Study: the Impact of Financial and Non- Financial Rewards on Non-Financial Rewards on Employee. International Journal of Business, 21(10), 1776-1786. https://doi.org/10.5829/idosi.mejsr.2014.21.10.21 756

[63] Sami, P., Sabri, U., Ilyas, M., \& Amjad, Z. (2011). Organizational Culture and Its Impact on the Job Satisfaction of the University Teachers of Lahore Pirzada Sami Ullah Sabri. International Journal of Business and Social Science, 2(24), 121-129.

[64] San Park, J., \& Hyun Kim, T. (2009). Do types of organizational culture matter in nurse job satisfaction and turnover intention? Leadership in Health Services, 22(1), 20-38. https://doi.org/10.1108/17511870910928001

[65] Sanda, M. A., \& Kuada, J. (2016). Influencing dynamics of culture and employee factors on retail banks' performances in a developing country context. Management Research Review, 39(5), 599-628. https://doi.org/10.1108/MRR04-2015-0078

[66] Sanda, M.-A., \& Kuada, J. (2016). Influencing dynamics of culture and employee factors on retail banks' performances in a developing country context. Management Research Review, 39(5), 599-628. https://doi.org/10.1108/MRR04-2015-0078

[67] Sarstedt, M., Ringle, C. M., Henseler, J., \& Hair, J. F. (2014). On the Emancipation of PLS-SEM: A Commentary on Rigdon (2012). Long Range Planning, $47(3)$, 154-160. https://doi.org/10.1016/j.lrp.2014.02.007 
[68] Saunders, M. N., Lewis, P., \& Thornhill, A. (2015). Research Methods for Business Students EBook. Pearson Australia Pty Limited

[69] Sohail, S., Rasul, F., \& Fatima, U. (2017). Is internal and external mechanism of governance enriching the performance of the banking sector of Pakistan? Corporate Governance (Bingley), 17(4), 629-642. https://doi.org/10.1108/CG-052016-0116

[70] Song, J. H. (2016). The Effect of Social Capital on Organizational Performance in Different Cultures: A Cross-National Comparison of the United States and South Korea. 1-201. https://doi.org/10.25148/etd.FIDC000712

[71] Spector, P. E. (1997). Job satisfaction: Application, assessment, causes, and consequences (Vol. 3). Sage publications.

[72] Spector, P. E. (1997). Job satisfaction: Application, assessment, causes, and consequences (Vol. 3). Sage publications.

[73] Top, M., Akdere, M., \& Tarcan, M. (2015). Examining transformational leadership, job satisfaction, organizational commitment and organizational trust in Turkish hospitals: public servants versus private sector employees. In International Journal of Human Resource Management (Vol. 26, Issue 9, pp. 1259-1282). Taylor $\&$ Francis. https://doi.org/10.1080/09585192.2014.939987

[74] Uzkurt, C., Kumar, R., Kimzan, H. S., \& Eminoğlu, G. (2013). Role of innovation in the relationship between organizational culture and firm performance: A study of the banking sector in Turkey. European Journal of Innovation Management, $\quad$ 16(1), 92-117. https://doi.org/10.1108/14601061311292878

[75] Uzkurt, C., Kumar, R., Semih Kimzan, H., Eminoğlu, G., Kimzan, H. S., Eminoğlu, G.,
Semih Kimzan, H., Eminoğlu, G., Kimzan, H. S., Eminoğlu, G., \& Authors, F. (2013). Role of innovation in the relationship between organizational culture and firm performance: A study of the banking sector in Turkey. European Journal of Innovation Management, 16(1), 92117.

https://doi.org/10.1108/14601061311292878

[76] Valmohammadi, C., \& Roshanzamir, S. (2015). The guidelines of improvement: Relations among organizational culture, TQM and performance. International Journal of Production Economics, 164 ,

$167-178$.

https://doi.org/10.1016/j.ijpe.2014.12.028

[77] Yesil, S., \& Kaya, A. (2013). The Effect of Organizational Culture on Firm Financial Performance: Evidence from a Developing Country. Procedia - Social and Behavioral Sciences, 81 , 428-437. https://doi.org/10.1016/j.sbspro.2013.06.455

[78] Yildirim, S., Acaray, A., \& Aydin, K. (2017). Exploring the impact of marketing culture on job satisfaction: Evidence from the Turkish banking sector. World Journal of Entrepreneurship, Management and Sustainable Development, 13(2),

$151-162$ https://doi.org/10.1108/WJEMSD-01-2017-0001

[79] Yildı, E. (2014). A Study on the Relationship between Organizational Culture and Organizational Performance and a Model Suggestion. 3(4), 52-67.

[80] Yilmaz, C., \& Ergun, E. (2008). Organizational culture and firm effectiveness : An examination of relative effects of culture traits and the balanced culture hypothesis in an emerging economy. Journal of World Business, 43(3), 290-306.

https://doi.org/10.1016/j.jwb.2008.03.019 
[81] Yuen, K. F., Loh, H. S., Zhou, Q., \& Wong, Y. D. (2018). Determinants of job satisfaction and performance of seafarers. Transportation Research Part A: Policy and Practice, 110(2013), 1-12. https://doi.org/10.1016/j.tra.2018.02.006

[82] Zahari, I. Bin, \& Shurbagi, A. M. A. (2012). The Effect of Organizational Culture and the Relationship between Transformational Leadership and Job Satisfaction in Petroleum Sector of Libya. International Business Research, 5(9), 89-97. https://doi.org/10.5539/ibr.v5n9p89

[83] Zakari, M., Poku, K., \& Owusu-Ansah, W. (2013). Organizational Culture and Organisational Performance : Empirical Evidence from the Banking Industry in Ghana. International Journal of Business, Humanities and Technology, 3(1), 95-107. http://www.ijbhtnet.com/journals/Vol_3_No_1_J anuary_2013/12.pdf

[84] Zeffane, R., \& Bani Melhem, S. J. (2017). Trust, job satisfaction, perceived organizational performance and turnover intention: A publicprivate sector comparison in the United Arab Emirates. Employee Relations, 39(7), 11481167. https://doi.org/10.1108/ER-06-2017-0135 